\begin{tabular}{c} 
Volume and Issues Obtainable at Center for Sustainability Research and Consultancy \\
Sustainable Business and Society in Emerging Economies \\
ISSN: $2708-2172$ (E): $2708-2504$ \\
Volume 2: Issue 2 December 2020 \\
Journal homepage: $\underline{w w w . p u b l i s h i n g . g l o b a l c s r c . o r g / s b s e e}$ \\
\hline
\end{tabular}

\title{
Ethical Behavioural Disclosure and Financial Performance of Listed Industrial Goods Firms in Nigeria
}

\begin{tabular}{|c|c|}
\hline \multicolumn{2}{|c|}{$\begin{array}{c}\text { 1Onipe Adabenege Yahaya, }{ }^{2} \text { Musa Jimoh Yusuf } \\
{ }^{1} \text { Department of Accounting, Nigerian Defence Academy, Kaduna, Nigeria, yoadabenege@nda.edu.ng } \\
{ }^{2} \text { Dept. of Finance \& Accounts, Nigerian Institute of Animal Science, Abuja, Nigeria, } \\
\text { musa.yusuf@nias.gov.ng }\end{array}$} \\
\hline ARTICLE DETAILS & ABSTRACT \\
\hline $\begin{array}{l}\text { History: } \\
\text { Revised format: November, } \\
2020 \\
\text { Available Online: December, } \\
2020\end{array}$ & $\begin{array}{l}\text { Purpose: Interests in the nexus between ethical performance and } \\
\text { financial performance have generated mixed results. However, despite } \\
\text { the number and the variety of studies, the evidences available suggest } \\
\text { not been comprehensively examined. Also, there is no sufficient effort } \\
\text { to examine this relationship within the industrial good sector in }\end{array}$ \\
\hline $\begin{array}{l}\text { Keywords: } \\
\text { Etical, Financial } \\
\text { performance, Nigeria, } \\
\text { Industrial Goods }\end{array}$ & $\begin{array}{l}\text { Nigeria. This calls for further study. Design/Methodology/Approach: } \\
\text { This study uses a functional coefficient regression technique to } \\
\text { estimate panel-varying betas and alpha in three financial performance } \\
\text { models. The empirical data were collected from the Nigerian Stock }\end{array}$ \\
\hline $\begin{array}{l}\text { JEL Classification: } \\
C 33, G 30, H 32, L 16, M 16\end{array}$ & $\begin{array}{l}\text { Exchange over a period of 2010-2019. Data were analyzed using } \\
\text { random effects models after accounting for multicollinearity, } \\
\text { heteroskedasticity, normality. Findings: Results show that human } \\
\text { resource development disclosure and community service disclosure } \\
\text { have noteworthy progressive effects on performance, environmental } \\
\text { and product safety disclosures have significant negative effects on } \\
\text { profit. Implications/Originality/Value: The study therefore concludes } \\
\text { that ethical behavioural practices of listed industrial firms have } \\
\text { significant effects on financial performance. The study recommends } \\
\text { among others that industrial firms should redirect their ethical practices } \\
\text { into human resource development and community services since their } \\
\text { disclosures enhance financial performance. }\end{array}$ \\
\hline
\end{tabular}

\section{OPEN ACCESS}

(C) 2021 The authors, under a Creative Commons AttributionNonCommercial 4.0

Corresponding author's email address: yoadabenege@nda.edu.ng

Recommended citation: Yahaya, O. A., \& Yusuf, M. J. (2020). Ethical Behavioral Disclosure and financial performance of listed industrial goods firms in Nigeria. Sustainable Business and Society in Emerging Economies, 2 (2), 13-20

\section{Introduction}

Companies with a strong ethical behaviour tend to maintain a higher degree of stakeholder satisfaction, positively influencing the financial results of the company (Duggan, 2017). Corporate ethic is seen as an indicator of corporate social responsibility (Ahmed, 2016; Maisaje, 2015; Vieira, 2013). Although, the term corporate social responsibility is more encompassing, corporate ethical behaviour is attracting 
interests among scholars in recent time. Firm's ethical behavioural practices are seen from the perspective of their involvement in human resource development, environment, community service and product safety. The underlying question is whether firms that ethically behaved and disclose such behaviour in their annual reports and accounts would have better financial performance?

Firm financial performance is of interest to stakeholders, after all, the primary firm goal is to maximize shareholders' wealth and by extension maximize the wealth of other stakeholders. Financial performance is seen within the context of return on assets, return on equity and earnings per share. Of interest in this study is whether firm disclosure of ethical behaviour could influence them? In order to achieve the objectives, the following hypotheses were developed and tested.

$\mathrm{H}_{\mathrm{oa}}$ : Human resource development disclosure has no significant effect on financial performance.

$\mathrm{H}_{\mathrm{ob}}$ : Environmental reporting has no significant effect on financial performance of listed industrial firms in Nigeria.

$\mathrm{H}_{\mathrm{oc}}$ : Community service reporting has no significant of listed industrial firms in Nigeria.

$\mathrm{H}_{\mathrm{od}}$ : Product safety disclosure does not significantly effect of listed industrial companies in Nigeria.

The study is limited to industrial goods and covers 2010-2019. The study is useful to a number of stakeholders such as shareholders, management, employees, governments, communities, civil societies involved in environment, Standards Organization of Nigeria. Also, the study contributes to understanding of theories, methodologies and empirics relating to the nexus between firm's ethical behaviour and financial performance. Such linkage has important implications not only for industrial firms, investors and top executives but also for scholars. The remaining sections deals with review of literature, data and methodology, empirical results, interpretation, conclusion besides commendations.

\section{Literature Review}

The stakeholders' theory was most appropriate theory to explain the nexus between ethical behavioural practices of firms and their financial performance. This is because both subjects are stakeholders-centric. Amir (2010) assesses consequence of ethical behaviour on profit in Uganda. Findings reveal that there is a significant positive relationship between ethical behaviour and financial performance. Kim (2010) examines link amongst ethical behaviour and long-term profit using archival data in South Korea. Results show ethical behaviour is related. Similarly, Joseph (2010) analyzes association between ethical behaviour and organizational result. Findings reveal moral behaviour has significant effect.

Micah et al. (2012) examine the relationship between firm's financial performance and human resource disclosure of companies in Nigeria using fifty-two firms over 2005-2009. Results indicate significant effect. Vieira (2013) analyzes the effects of ethical behaviour on a firm's financial profitability using Portuguese construction industry. After analyzing the financial indicators (return on assets and profit margin) the paper concludes that return on assets stands suggestively connected with ROA. The study failed to find evidence that connect profit margin to morality.

Elayan et al. (2014) examine the impact of firms acting ethically on financial performance. The study assesses the impact of quarterly changes in the Covalence Ethics Index (CEI) rankings compared to firm financial performance (FP). A significant positive stock market reaction to CEI upgrades was observed. Berrone et al. (2015) empirically assess the impact of corporate ethical behaviour (CEB) on firm's financial performance. Drawing on normative and instrumental stakeholder theory, they argue that firms with a strong ethical behaviour achieve greater degree of financial performance. Enofe et al. (2015) examine the relationship between ethical behaviour and ROTA amongst banks in Nigeria. The empirical result indicates that ethical behaviour was significant and positive.

Ewekpa and Ewans (2015) discovered concludes that morality enhance performance among banks in Nigeria. Ebitu and Beredugo (2015) investigate the relationship between ethics and performance of 
service industry in Nigeria and result shows significance. Adebawojo et al. (2015) uses 18 publicly quoted banks in Nigeria and the analyses confirmed that human asset accounting significantly affects the banks' performance.

Persons (2016) investigates link amongst ethics and profitability using 94 companies from USA. Logit regression analysis indicates firm without ethical behaviour had poorer financial performance. The regression analysis suggests that not having a code of ethical behaviour.

Halamka and Teply (2017) investigate how ethics affect financial performance. They suggest that moral banks report lower dispersion in ROE. Also, Uwuigbe et al. (2017) examine the degree of influence of ethical reporting in annual reports of listed firms in Nigeria on financial performance for the period 2010-2014. Findings from the paper show there a significant relationship between ethical reporting and financial performance. Also, Ahmed et al (2017) use 35 companies in Nigeria covering 10 years (2006 2015). The study finds that human resource disclosure has significant and positive effect on ROTAA, ROEQ and ROCED.

\section{Methodology}

The firms were qualitatively and dichotomously measured ( 1 for item reported and 0 otherwise). This was achieved through content analysis by analyzing the four different indexes that companies show ethical commitment: human resource development, environment, community service and product safety. Data on financial performance indicators (return on assets, return on equity and earnings per share) were obtained by computing ratios from the Nigerian Stock Exchange. REM was used to analyze statistics after carrying out panel effects, normality, multicollinearity, heteroskedasticity and serial correlation tests. The study uses a longitudinal panel research design. Sample was made up of the 24 listed industrial firms in Nigeria.

$$
\begin{aligned}
& \operatorname{rota}_{i, t}=\alpha+\beta_{1} \text { hrdi }_{i, t}+\beta_{2} \text { envi } i_{i, t}+\beta_{3} \text { ssi }_{i, t}+\beta_{4} p s i_{i, t}+\beta_{5} \text { size }_{i, t}+\beta_{6} \text { lev }_{i, t}+\beta_{7} \text { grow }_{i, t}+e_{i, t} \ldots \ldots \text { (1) } \\
& \text { roeq }_{i, t}=\alpha+\beta_{1} \text { hrdi }_{i, t}+\beta_{2} \text { envi } i_{i, t}+\beta_{3} \text { csi }_{i, t}+\beta_{4} p s i_{i, t}+\beta_{5} \text { size }_{i, t}+\beta_{6} \text { lev }_{i, t}+\beta_{7} \text { grow }_{i, t}+e_{i, t} \ldots . . \text { (2) }
\end{aligned}
$$

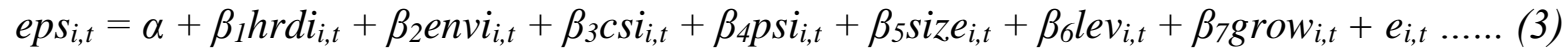

\section{Wherever:}

rota $=$ Return on total assets as profit before tax/total assets (Al-Taani, 2013; Joliet \& Muller, 2013; Mitani, 2014; Visic, 2013; Yahaya, 2015).

roeq $=$ Return on equity, as profit after tax/equity (Nirajini \& Priya, 2013; Pouraghajan et al., 2012; Visic, 2013; Yahaya, 2015).

eps = Earnings per stock as profit after tax/equity shares (Yahaya, Tanko \& Muhammad, 2017).

$\alpha=$ Constant (alpha) assuming that all exploratory variables and control variables are 0 .

$\beta_{1}-7=$ Beta coefficients of the exploratory and control variables.

$h r d i=$ Human resource development index derived from indices of training programs, schemes, educational facilities, in-house training, establishment of training centres, sponsoring educational conferences and seminars (Ahmed, 2016; Maisaje, 2015).

envi $=$ Environmental index (Vieira, 2013).

csi $=$ Community service (Maisaje, 2015; Vieira, 2013).

$p s i=$ Product safety index derived from safety of company's products, whether the products meet applicable standards (Ahmed, 2016).

size $=$ Firm size as log base 10 of total asset (Smith et al., 2012; Soumadi \& Hayajneh, 2012; Yahaya, 2016).

$l e v=$ Leverage, measured as total liabilities divided by equity (Yahaya \& Andow, 2015).

grow $=$ Growth, measured as change in total assets $x 100$ (Soumadi \& Hayajneh, 2012; Voulgaris et al., 2011; Yahaya, Tanko \& Muhammad, 2017).

$i=$ Firm subscript (in this case, 24);

$t=$ Time period covered (in this case, 10 years) 
$\varepsilon=\operatorname{Idiosyncratic}\left(\right.$ Stochastic) error term $\left(\lambda_{\mathrm{i}}, \varepsilon_{\mathrm{i}, \mathrm{t}}\right)$

\section{Data Analysis and Results}

The summary statistics of the data set are reported in Table 1.

Table 1: Statistical Indicators

\begin{tabular}{llrrrr}
\hline Variable & Observ. & Average Mean & Std. Deviation & Mini & Maxi \\
\hline rota & 240 & .291 & .162 & .05 & .78 \\
roeq & 240 & .337 & .160 & 0 & .7 \\
eps & 240 & .188 & .099 & .039 & .512 \\
hrdi & 240 & .561 & .154 & 0 & .82 \\
envi & 240 & .394 & .207 & .11 & .85 \\
csi & 240 & .609 & .139 & .3 & .89 \\
psi & 240 & .551 & .060 & .45 & .75 \\
size & 240 & 15.823 & 1.418 & 12.633 & 17.684 \\
lev & 240 & .465 & .205 & .098 & 1.365 \\
grow & 240 & .002 & .058 & -.286 & .191 \\
\hline
\end{tabular}

Source: STATA 13 Outputs

As shown in Table 1, the number of observation for all the variables are 240, suggesting that the data set are strongly balanced. Also, the mean statistic values of roa, roe and eps are $0.291,0.337$ and 0.188 respectively. These results suggest that roe has the highest standard measure of the centre of the distribution among the dependent variables. However, among the independent variables, csi (0.609) has the highest measure of the centre of the distribution. Similarly, size (15.823) has the highest measure of the centre of the distribution among the control variables.

In this regard, roa (0.162) has a greater spread among the dependent variables; envi (0.207) has a greater spread among the independent variables and size (1.418) has a greater spread among the control variables. Also, as Table 1 shows, roe (0) has the lowest mean among the dependent variables; hrdi (0) has the lowest mean among the independent variables and grow $(-0.286)$ has the lowest mean among the control variables. In the same vein, roa (0.780) has the highest mean among the dependent variables; $c s i$ (0.89) has the highest mean among the independent variables and size (17.684) has the highest mean among the control variables. Table 2 displays the results of multicollinearity test. This test discloses whether the variances among the predicting variables are inflated or not. A VIF of 1 suggests correlation.

Table 2: Results of Association Check

\begin{tabular}{lll}
\hline Var. & Var. Inf. Factor & $1 /$ Var. Inf. Factor \\
\hline csi & 1.95 & 0.512 \\
size & 1.79 & 0.557 \\
lev & 1.60 & 0.625 \\
psi & 1.48 & 0.677 \\
envi & 1.34 & 0.747 \\
hrdi & 1.25 & 0.798 \\
grow & 1.14 & 0.874 \\
Mean VIF & 1.51 & \\
\hline
\end{tabular}

Source: STATA 13 Outputs

As shown in Table 2, the VIFs of all the variables are less than 4, indicating absence of multicollinearity among the independent and control variables. These results are consistent with the advantage of using panel data, less collinearity. Three important assumptions are that (1) the variance in the residuals has to be homoskedastic, which means constant; (2) the null is no serial correlation and (3) the panel effect is random. 
Table 3: Hettest, Auto link and Hausman specification investigations

\begin{tabular}{lrrrrrr}
\hline Model & \multicolumn{2}{c}{$\begin{array}{c}\text { Heteroskedasticity } \\
\mathrm{Chi}^{2}(1)\end{array}$} & Prob $>\mathrm{Chi}^{2}$ & Serial (Auto) Correlation & \multicolumn{2}{c}{ Hausman Specification Test } \\
& 17.54 & 0.000 & 20.349 & 0.0002 & 8.38 & 0.3000 \\
\hline rota & 2.20 & 0.138 & 10.616 & 0.0035 & 7.49 & 0.3800 \\
roeq & 24.07 & 0.000 & 83.368 & 0.000 & 13.65 & 0.0577 \\
eps & & & & &
\end{tabular}

Source: STATA 13 Outputs

The null is homoscedasticity (or constant variance). As shown in Table 3, the results suggest the rejection of the null (since p-value < 0.05) and conclude that there is heteroskedasticity in 2 models. However, there is no heteroskedasticity in model roe ( $\mathrm{p}$-value $=0.138$ ). Similarly, the results suggest that the three models have serial (auto) correlation problem and conclude that the models have firstorder autocorrelation. In addition, the p-values from the Hausman specification test are $>5$ per cent (accept the null hypotheses) results show that the most appropriate panel effects model for the study is the random effects model (REM) since the Prob $>\mathrm{Chi}^{2}$ values are not significant.

Another important assumption is error of the model is generally allocated, that is, null is normal distribution ( $\mathrm{p}$-value $<5$ per cent). Table 4 displays Shapiro Wilk test for normal data.

Table 4: Results of Distribution

\begin{tabular}{llllll}
\hline Var. & Observ. & $\mathrm{W}$ & $\mathrm{V}$ & $\mathrm{Z}$ & Probability $>\mathrm{z}$ \\
\hline rota & 240 & 0.944 & 9.815 & 5.303 & 0.000 \\
roeq & 240 & 0.988 & 2.089 & 1.711 & 0.044 \\
eps & 240 & 0.946 & 9.463 & 5.218 & 0.000 \\
hrdi & 240 & 0.856 & 25.155 & 7.488 & 0.000 \\
envi & 240 & 0.943 & 10.052 & 5.359 & 0.000 \\
csi & 240 & 0.989 & 1.848 & 1.426 & 0.077 \\
psi & 240 & 0.952 & 8.453 & 4.956 & 0.000 \\
size & 240 & 0.921 & 13.788 & 6.092 & 0.000 \\
lev & 240 & 0.872 & 22.344 & 7.213 & 0.000 \\
grow & 240 & 0.586 & 72.466 & 9.945 & 0.000 \\
\hline
\end{tabular}

Source: STATA 13 Outputs

As shown in Table 4, all the variables with the exception of $c s i$ are not normally distributed. Table 5 reports regression with Newey-West standard errors after accounting for diagnostic checks (multicollinearity, heteroskedasticity, serial correlation, normality and panel effects) as Tables 2-4 indicate.

Table 5: Results of Newey Regression

\begin{tabular}{lrrrrrrrrr}
\hline Model & \multicolumn{3}{c}{ rota } & \multicolumn{3}{c}{ roeq } & eps \\
Var. & Coef. & t-value & $\operatorname{Pr}>\mathrm{t}$ & Coeff. & t-value & $\operatorname{Pr}>t$ & Coeff. & t-value & $\operatorname{Pr}>\mathrm{t}$ \\
\hline hrdi & .366 & 4.63 & 0.000 & .379 & 5.64 & 0.000 & .115 & 2.83 & 0.005 \\
envi & -.230 & -4.30 & 0.000 & -.180 & -3.42 & 0.001 & -.098 & -3.32 & 0.001 \\
csi & .337 & 3.61 & 0.000 & .493 & 5.85 & 0.000 & .337 & 6.35 & 0.000 \\
psi & -.457 & -2.13 & 0.034 & -.366 & -1.50 & 0.135 & -.390 & -3.38 & 0.001 \\
size & -.0120 & -1.69 & 0.092 & -.0341 & -4.99 & 0.000 & -.007 & -1.20 & 0.231 \\
lev & .0315 & 0.69 & 0.492 & -.040 & -0.88 & 0.378 & .020 & 0.87 & 0.385 \\
grow & -.225 & -1.34 & 0.182 & .181 & 1.42 & 0.157 & .166 & 1.97 & 0.050 \\
cons & .395 & 2.36 & 0.019 & .655 & 4.03 & 0.000 & .271 & 2.26 & 0.025 \\
Prob>F & & 0.000 & & & 0.000 & & & 0.000 & \\
\hline
\end{tabular}

Source: STATA 13 Outputs

In Table 5, hrdi was important and confident effect on roa $($ Coef $=0.366, \mathrm{t}=4.63, \mathrm{P}>\mathrm{t}=0.000)$, roe $($ Coef $=0.379, \mathrm{t}=5.64, \mathrm{P}>\mathrm{t}=0.000)$ and eps $(\mathrm{Coef}=0.115, \mathrm{t}=2.83, \mathrm{P}>\mathrm{t}=0.005)$. These results are in line with the results of Ahmed, Yahaya and Mustapha (2017). Similarly, csi shows significant and positive effect on roa $($ Coef $=0.337, \mathrm{t}=3.61, \mathrm{P}>\mathrm{t}=0.000)$, roe $($ Coef $=0.493, \mathrm{t}=5.85, \mathrm{P}>\mathrm{t}=0.000)$ and eps $(\mathrm{Coef}=0.337, \mathrm{t}=6.35, \mathrm{P}>\mathrm{t}=0.000)$. However, envi shows significant and negative effect on roa $($ Coef $=-0.230, \mathrm{t}=-4.30, \mathrm{P}>\mathrm{t}=0.000)$, roe $($ Coef $=-0.180, \mathrm{t}=-3.42, \mathrm{P}>\mathrm{t}=0.001)$ and eps $(\mathrm{Coef}=-$ 
0.098, $\mathrm{t}=-3.32, \mathrm{P}>\mathrm{t}=0.001)$. Similarly, psi shows significant and negative effect on roa $($ Coef $=-0.457$, $\mathrm{t}=-2.13, \mathrm{P}>\mathrm{t}=0.034)$, and eps $($ Coef $=-0.390, \mathrm{t}=-3.38, \mathrm{P}>\mathrm{t}=0.001)$ but insignificant and negative effect on roe $($ Coef $=-0.366, \mathrm{t}=-1.50, \mathrm{P}>\mathrm{t}=0.135)$. Taking the results together, Table 5 shows that ethical behavioural disclosure of industrial firms has significant effect. These results agree with Amir (2010), Berrone et al. (2015), Cuomo et al. (2016), Ebitu and Beredugo (2015), Elayan et al. (2014), Enofe et al. (2015), Ewekpa and Ewans (2015), Halamka and Teply (2017), Joseph (2010), Kim (2010), Persons (2016) and Uwuigbe et al. (2017).

For the control variables, size shows significant and negative effect on roe $($ Coef $=-0.0341, t=-4.99$, $\mathrm{P}>\mathrm{t}=0.000)$ and insignificant and negative effects on roa $(\operatorname{Coef}=-0.0120, \mathrm{t}=-1.69, \mathrm{P}>\mathrm{t}=0.092)$ and eps $($ Coef $=-0.007, \mathrm{t}=-1.20, \mathrm{P}>\mathrm{t}=0.231)$. Lev shows insignificant effect on roa $($ Coef $=0.0315, \mathrm{t}=$ $0.69, \mathrm{P}>\mathrm{t}=0.492)$, roe $($ Coef $=-0.040, \mathrm{t}=-0.88, \mathrm{P}>\mathrm{t}=0.378)$ and eps $($ Coef $=0.020, \mathrm{t}=0.87, \mathrm{P}>\mathrm{t}=$ 0.385). Grow shows significant and positive effect on eps $($ Coef $=0.166, \mathrm{t}=1.97, \mathrm{P}>\mathrm{t}=0.050)$ but insignificant effects on roa $($ Coef $=-0.225, \mathrm{t}=-1.34, \mathrm{P}>\mathrm{t}=0.182)$ and roe $(\mathrm{Coef}=0.181, \mathrm{t}=1.42, \mathrm{P}>\mathrm{t}=$ 0.157).

\section{Conclusion}

The study examined association between ethical behaviour and financial performance of listed industrial goods corporations. This paper used data set from twenty-four firms over a period of ten years $(2010-$ 2019) resulting in 240 observations. On the strength of the results, the study concludes that human resource development disclosure and community service disclosure have significant and positive influences on financial performance. The study also concludes that environmental disclosure and product safety disclosure have significant and negative influences on financial performance. With these conclusions, the paper commends industrial corporations strengthen disclosure of human resource development and community services and reduce disclosure of environmental and product safety measures.

\section{Rerences}

Adebawojo, O. A., Enyi, P. E., \& Adebawo, O. O. (2015). Human asset accounting and corporate performance. American International Journal of Contemporary Research, 5(1), 45 52.

Ahmed, M. N. (2016). Impact of corporate social responsibility disclosure on financial performance of listed firms in Nigeria. PhD Dissertation, Nigerian Defence Academy, Kaduna

Ahmed, M. N., Yahaya, O. A., \& Mustapha, L. O. (2017). Impact of human resource disclosure on financial performance of listed firms in Nigeria. Yobe Journal of Economics, 4(2), 182-204.

Al-Taani, K. (2013). The relationship between capital structure and firm performance:

Evidence from Jordan. Journal of Finance and Accounting, 1(3), 41-45.

Amir, L. (2010). Code of conduct and ethics on perceived financial performance in Uganda public service: a case of ministry of education and sports. M. Sc Thesis, Makerere University.

Berrone, P., Surroca, J., \& Tribo, J. A. (2015). Corporate ethical identity as determinant of firm performance: a test of the mediating role of stakeholder satisfaction. Working Paper 05-31, Universidad Carlos III de Madrid.

Cuomo, M. T., Tortora, D., Mazzucchelli, A., Festa, G., di Gregorio, A., \& Metallo, G. (2016). Effects of corporate ethical practices on financial performance in the Italian banking services listed companies. 19th Toulon-Verona International Conference Proceedings, University of Huelva, Spain.

Duggan, T. (2017). How do ethics affect the financial results of a company? www.cron.com.

Ebitu, E. T., \& Beredugo, S. B. (2015). Business ethics and the performance of service firms in Calabar, Cross River State, Nigeria. European Journal of Hospitality and Tourism Research, 3(2), 28-38.

Elayan, F. A., Li, J., Liu, Z. F., Meyer, T. O., \& Felton, S. (2014). Ethical performance, 
financial performance and the quality of financial reporting. Brock University, St. Catharines, Ontario, Canada.

Enofe, A. O., Ekpulu, G. A., Onobun, S. I., \& Onyeokweni, V. O. (2015). Ethical challenges and financial performance in the Nigerian banking sector. Research Journal of Finance and Accounting, 6(10), $1-11$.

Ewekpa, K. C., \& Ewans, C. (2015). Business ethics and corporate performance in the banking industry: A study of selected banks in the South East Nigeria. International Journal of Research in Business Management, 3(10), 15-22.

Halamka, R., \& Teply, P. (2017). The effect of ethics on banks'financial performance. MyIDEAS.

Gatimbu, K. K., \& Wabwire, J. M. (2016). Effect of corporate environmental disclosure on financial performance of firms listed at Nairobi Securities Exchange, Kenya. International Journal of Sustainability Management and Information Technologies, 2(1), 1-6.

Joliet, R., \& Muller, A. (2013). Capital structure effects of international expansion. Journal of Multinational Financial Management, 375-393.

Joseph, K. O. (2010). Effects of ethical behaviour on organizational performance: Evidence from three service organizations in Lagos, Nigeria. Journal of Research in National Development, 8(1), $71-85$.

Kim, J. W. (2010). Assessing the long-term financial performance of ethical companies. Journal of Targeting, Measurement and Analysis for Marketing, 18(3-4), 199-208.

Maisaje, J. I. (2015). Impact of corporate social responsibility on firm financial performance. MSc Thesis, Nigerian Defence Academy.

Micah, L. C., Ofurum, C. O., \& Ihendinihu, J. U. (2012). Firms Financial Performance and Human Resource Accounting Disclosure in Nigeria. International Journal of Business and Management, 7(14), 67 - 75. doi:10.5539/ijbm.v7n14p67.

Mitani, H. (2014). Capital structure and competitive position in product market. International Review of Economics and Finance 29, 358-371.

Nirajini, A., \& Priya, K. B. (2013). Impact of Capital Structure on Financial Performance of the Listed Trading Firms in Sri Lanka. International Journal of Scientific and Research Publications, 3(5), 54-67.

Persons, O. S. (2016). Characteristics and financial performance of no-ethics-code firms. Journal of Academic and Business Ethics, 12(2), 1-14.

Pouraghajan, L., Malekian, K., Emamgholipour, H., Lotfollahpour, L., \& Bagheri, B. (2012). The relationship between capital structure and firm performance evaluation measures: Evidence from the Tehran Stock Exchange. International Journal of Business and Commerce, 1(9), 166181.

Smith, C., Anderson, D. J., \& Hamish, D. (2012). The relationship between capital structure and product markets in evidence from New Zealand. Review of Quantitative Finance and Accounting, 38, 1-24.

Soumadi, M. M., \& Hayajneh, O. S. (2012). Capital structure and corporate performance Empirical study on the Jordanian shareholdings firms listed in the Amman stock market. European Scientific Journal, 8(22), 173-189.

Souza, G. H. C., Felix Jnr, L. A., Lagioia, U. C. T., \& de Araujo, J. G. N. (2016). Financial performance and information disclosure on human resources: an analysis of companies in The IBrX - 100. Journal of Education and Research in Accounting, 10(1), 88-102. doi: http://dx.doi.org/10.17524/repec.v10i1.1320.

Uwuigbe, U., Olugbenga, J., Uwuigbe, O. R., Peters, L., \& Adegbola, O. (2017). Corporate ethical reporting and financial performance: Evidence from the emerging market. Risk Governance and Control: Financial Markets and Institutions, 7(4), 14 - 22. doi: $10.22495 /$ rgc7i4art2.

Vieira, M. E. R. (2013). The effects of ethical behaviour on profitability of firms - A study Portuguese construction industry. Dissertation, Polytechnic Technology, Portugal. 
Visic, J. (2013). Impact of takeovers on profitability of target companies: Evidence from Croatian companies. Croatia Communist and Post-Communist Studies, 46, 455-461.

Voulgaris, G., Stathopoulos, K., \& Walker, M. (2011). IFRS and the use of accountingbased performance measures in executive pay. Working Paper. University of Edinburgh, Scotland.

Yahaya, O. A., \& Andow, H. A. (2015). Capital structure and firm's financial performance: Panel evidence of listed conglomerate firms in Nigeria. Kaduna Business Management Review, 2(1), 1-25.

Yahaya, O. A. (2016). Effects of International financial reporting standards on financial statements of listed deposit money banks in Nigeria. PhD Dissertation, Nigerian Defence Academy, Kaduna.

Yahaya, O. A. (2017). Firm performance and dividend policy: A panel data analysis of listed consumer-goods companies in Nigeria. Nigerian Journal of Management Technology and Development, 8(1), 306-322.

Yahaya, O. A., Tanko, M., \& Muhammad, L. M. (2017). Effects of corporate characteristics on earnings quality of listed deposit money banks in Nigeria. Kaduna State University Journal of Management Sciences, 8(1), 47-64. 